\title{
Carlo COMANDUCCI
}

\section{The Emancipated Theorist: Indisciplinarity and the Academia}

\begin{abstract}
By refusing a distribution of roles between theorists and spectators, between critical and non-critical subjects, Jacques Rancière's theory of intellectual emancipation is in some ways anticipating the eclipse of film theory and of critical theory as academic disciplines.

The indisciplinarity advocated by Rancière requires a redefinition of academic practice as something else than what is practised by academics. In this sense, the academia should not be conceived as a place where a specific kind of people comes together, but as a common scene of critical reflection that has no proper place, where knowledge comes to exist as a common and that anybody can occupy at any time without qualification.

Retracing the anti-disciplinary implications of Rancière's argument on the spectator's emancipation, the article will discuss an indisciplinary approach to the understanding of critical theory and the academia.
\end{abstract}

Keywords: Academia, the Common, Critical theory, Discipline, Emancipation, Indisciplinarity, Jacques Rancière.

"The university ... is the appropriable city."

Paul Goodman, The Community of Scholars.

\section{Problematisation}

Asked a few years ago to define his contribution to the French intellectual scene, Jacques Rancière refrained from naming any of his specific achievements and replied instead with what we can regard as a synthetic formulation of one of the basic elements of his practice: "I try," he said, "to problematise the categories that structure diagnoses of our present and debates about it" (Rancière, Baronian and Rosello, "Jacques Rancière and Indisciplinarity" 1).

\section{Carlo COMANDUCCI}

Vistula University, Warsaw

c.wayward@zoho.com

EKPHRASIS, 1/2018

Aftermaths of Critical Theory

pp. 22-35

DOI:10.24193/ekphrasis.19.3

Published First Online: 2018/06/20 
This kind of problematisation is indeed familiar to his readers. Where common understanding sees only the passivity of a subject relinquishing its own agency, Rancière sees the basic ground of emancipation; where teaching is more or less tacitly conceived as a transmission of the information that a teacher has come to possess and understand, he sees a relation that can take place independently from what the teacher knows; what is usually considered to be democracy, turns out to be the entrenched form of an aversion to it; where others say politics, he says police. These are not so much reversals meant to uncover the hidden logic of a phenomenon - à la Slavoj Žižek - than ways of stepping beside a situation in order to question the coordinates that sustain the existing ways of understanding it.

In relation to film studies, as well, Rancière's main interventions constitute a problematisation of the concepts that define the discipline: cinema is not treated as the field of an art individuated by a specific technology, but as a regime of understanding of all arts; the film image is not taken as a simple visual "given", but rather as a heterogeneous, pensive, composition and an embodied and situated experience; the spectator's presumed passivity is negated on the basis of a principle of intellectual equality; film theory and the critique of ideology are exposed as part of the apparatus they describe. All this does not merely result in a revision or an extension of the field of film studies, but in a reconfiguration so radical that it challenges its very existence as a discipline.

Moving away from both taxonomic analyses and a grand project of a film semiotics, for instance, the idea of constituting film theory at once as an academic discipline and as a meta-language of film is opposed by Rancière to cinema's fundamental heterogeneity:

"The idea that there is a filmic language, that you are going to distil the elements of this language, and that on this basis you are going to analyse films isn't, in my view, of much interest. This still pertains to the idea of disciplines and fields, whereas cinema intermingles different sensory regimes: those of the literary imagination, sensitive viewing of a painting, musical emotion, etc." (7)

Even more strongly, Rancière rejects disciplinary constitutions of film studies based on onto-technological, sociological and pedagogical assumptions. Forms of film theory that insist on linking the characteristic of film to the qualities of a technical apparatus, that infer the properties of film experience from the properties of a specific social and cultural "part" or subject position, and that reproduce the spectator's inequality by assuming its incapacity to understand the spectacle are presented not only as dispensable, but as outrightly malicious.

It may be true then that, as Nico Baumbach argued, "the recent currency of Jacques Rancière might be attributable to the fact that he has offered a new vocabulary for posing the link between aesthetics and politics" without either recurring to the "old models" of apparatus theory or acquiescing to the shift toward analytic philosophy, the cognitive or the social sciences (Dissensus 68). But Rancière's work does something 
more radical than merely providing a comfortable middle ground between 1970s Althusserian film theory and the cognitive turn, and actually puts into question the disciplinary foundations of both. Through Rancière, a discourse on the constitution of film studies and on the relation between the practice of theory and the dimension of spectatorship becomes absolutely central in the discussion of the politics and the aesthetics of cinema.

While, under various names, problematisation is a central concern of critical theory, feminist film theory, and of an anti-essentialist epistemology at large, Rancière's distinctive take on the issue in fact extends problematisation to the practice of theory in such a way as to make the concrete relations between theory and its object into the primary dimension of his work (see Bowman, Rancière and Film 5). Rancière's argument for the spectator's fundamental emancipation, his objections to the intellectual authority of the philosopher and the "sociologist king", and even his mistrust towards the devotions of "engaged" art, all depend on a problematisation of the relation between the subject and the object of knowledge, between the voice of the theorist or critical subject and that of the spectator. Disciplinarity and indisciplinarity, in this sense, are not just a matter of the articulation of a method or of the possible relations between disciplines, but of the politics and aesthetics of knowledge as such.

"My problem has always been to escape the division between disciplines," Rancière wrote, "because what interests me is the question of the distribution of territories, which is always a way of deciding who is qualified to speak about what. The apportionment of disciplines refers to the more fundamental apportionment that separates those regarded as qualified to think from those regarded as unqualified; those who do the science and those who are regarded as its objects." (Rancière, Baronian and Rosello, "Jacques Rancière and Indisciplinarity" 3)

In this sense, then, a discipline does not only name a set of methods and a positive knowledge (savoirs) that describe already existing objects, but a discourse that posits those objects in a certain way to begin with, as well as a practice that, through this positing and these descriptions, effects a distinction between kinds of subjects and distributes them to different places and roles. The problem of disciplinarity is thus connected with the question of politics, which is for Rancière fundamentally the question of who is entitled to speak.

"A discipline, in effect, is not first of all the definition of a set of methods appropriate to a certain domain or a certain type of object. It is first the very constitution of this object as an object of thought, the demonstration of a certain idea of knowledge - in other words, a certain idea of the rapport between knowledge and a distribution of positions." A discipline is also "a way of defining an idea of the thinkable, an idea of what objects of knowledge themselves can think and know. It is therefore always a certain regulation of dissensus [...]." (Rancière, "Thinking between Disciplines" 6)

As Caroline Pelletier has argued, the ways the discourse of science distinguishes itself from the voice of its object and demonstrates the truth of this distinction are 
what allows the constitution of a disciplinary field of knowledge in the first place (see Pelletier, "Rancière and the Poetics of the Social Sciences" 272-273) - so that a discourse on emancipation can only be done within an indisciplinary collapse of existing discourses and positions of enunciation.

\section{Politics and disciplines}

Generally speaking, scholarly theories and academic institutions always play a role in producing and confirming distributions of the sensible - that is, configurations of discourses and practices that outline what can be perceived and said, what can be thought and imagined and thus what is possible to realise. More specifically, through their validation of specific forms of knowledge and of knowing, through their preoccupation with the classification and explication of subject positions, and not least through their constant incitement to discourse (see Foucault 17), academic disciplines can be said to perform a disciplinary function in the Foucauldian sense. The connection between academic disciplines and disciplinary regulation is neither a mere quip nor a simple tautology, but is part of a consensual regime of understanding of knowledge, which Rancière's discussion of indisciplinarity is attempting to problematise.

Since it does not advocate a multiplication or a more elastic collaboration of disciplines but a break with the logic of disciplinarity itself, Rancière's indisciplinarity distinguishes itself from inter-disciplinarity and multi-disciplinarity, on one hand, and stands in clear opposition with the idea of a convergence of disciplines on the other.

When Rancière qualifies his work as "indisciplinary" (Rancière, Baronian and Rosello, "Jacques Rancière and Indisciplinarity" 2), he is concerned to negate the coincidence of the function of academic discourse and the function of what he calls the police - the consensual articulation and the comprehensive mapping of what can be seen and said, thought and done, that allows for neither gap nor conflict (Rancière, Dissensus 92).

For him, a critique of the distribution of the sensible - of what is present according to existing "diagnoses" - has to begin from an "indisciplinary" disarticulation of the theories that, both critically and uncritically, support that understanding of the world. A critical practice that starts from the same assumptions that structure a given distribution of the sensible, indeed, reinforces that distribution by arguing against a given wrong in the same terms that are sanctioning it. To problematise categories of understanding, then, means first of all to break up the consistency of the theories and the powers that distribute the seeable and the sayable according to those categories and that constitute themselves as disciplines on the basis of this distribution.

If to address a state of the world is to address the ways we make sense of it, a critical stance entails putting our established forms of knowledge, as well as the consensual criteria of what counts as knowledge and who is entitled to it, constantly in question. Indiscipline, Rancière stated, "is not only a matter of going besides the 
disciplines but of breaking them" (Rancière, Baronian and Rosello, "Jacques Rancière and Indisciplinarity" 2-3). The disciplines themselves are not completely dismissed, and the styles of knowing and the observations that extend from them are not ignored, but a particular regime of their operation is nevertheless dispensed with: that, precisely, which constitutes them as instruments of a distribution of roles. In the end, critique as the indisciplinary declassification of discourses and critique as the egalitarian disruption of existing distributions of roles go invariably together.

The political break is necessarily done within the existing distribution of the sensible (for the nature of the distribution is precisely to define a scene that, before this break, is perceived to be complete), but then transforms the scene as a whole. Politics, in this sense, is more a matter of seeing the world as it cannot be recognised to be, than a matter of the further or deeper explanation of the world as it apparently is, and more a matter of imagination than one of representation. So, in the case of the film spectator, the critique that Rancière performs is not a better mapping of the reality of spectatorship or spectatorships, or a demystification of the hidden mechanisms of ideology and oppression, but a theoretical break: a gesture that affirms the apparently unjustifiable assumption that emancipation already exists, that "the incapable are capable; that there is no hidden secret of the machine that keeps them trapped in their place" (Rancière, The Emancipated Spectator 48). This break in turn also threatens the existence of film theory as one of the fundamental disciplines and discourses that, precisely, make sense of the spectator as a position of passivity within a given distribution of roles and sensibilities.

Rancière argues that emancipation is less a matter of a conflict between established parts, less the articulation of what was previously under- or mis-represented, than the constitutional effect of a radical and irresolvable conflict. The political dimension comes into being not when the balance of power changes within the existing distribution of the parts, but when this distribution is troubled by a part of those that have no part (a part de sans parts), by the manifestation of something that is incommensurable with the very principles that regulate the distribution of the parts. This dimension ceases to exist, on the contrary, when the gap between the thinkable and the possible is closed and both experience and being-there are brought back within the intelligible articulations of discourse and the parts these articulations define in the social space. As it pursues intelligibility and a better and better mapping of the existent and the possible, then, and as it proceed by a finer and finer tuning of identification, the mise en discours (the putting into discourse) that characterises disciplinary academic practice must then be seen as a primary instrument of disciplinary regulation.

Thinking about the problem of the spectator's agency and emancipation in film studies, what is at stake in Rancière's shift from talking about a system of mystification (of which one could imagine to be outside) to talking about a distribution of perceptions (in which one always has a part) is precisely the idea that the political break cannot be made in the terms of things as they are already conceived and the positions that 
are already used to make sense of them, but must be a change of the existing regime of perception in its entirety. "Whereas misrecognition posits the epistemological and ethical value of science as its countervailing force," writes Pelletier, clearly referring of Althusser's conception of science, "disagreement insists on the disputed status of speech" ("Rancière and the Poetics of the Social Sciences" 276).

What this shift from mystification to disagreement suggests, therefore, is not only the necessity of affirming the spectator's emancipation but also that of thinking the dialogic dimension of spectatorship. In a first sense, the shift places spectatorship and spectatorship theory in one and the same dimension, a dialogic dimension where the experience of film is extended and discussed, thereby allowing to verify the lack of distinction between the subject of experience and the subject of knowledge. In a second sense, the dimension of film experience itself is reimagined as a logos and thus, to put it simply, the spectator is recognised not just the ability to speak for or against the existing discourses, but that to fashion unforeseen discourses and situations as well.

"Emancipation," Rancière has argued, "begins when we dismiss the opposition between looking and acting and understand that the distribution of the visible itself is part of the configuration of domination and subjection. It starts when we realize that looking is also an action that confirms or modifies that distribution and that 'interpreting the world' is already a means of transforming it, of reconfiguring it." (Rancière "The Emancipated Spectator" 277)

On one hand, Rancière is here defining the agency of the spectator - and, together with it, a much broader domain of its responsibility. On the other, he is condemning the distinction between the subject of knowledge and transformative action (the theorist, expert or critical subject) and the subject of the look (the ideologically and psychologically passive spectator) that is not just a staple of Althusserian film theory, but characterizes many strands of film theory even beyond the 1970s psychoanalysis and Marxism paradigm.

We may want to note that the use of the verb "realize" must be taken here to mean something more than the mere acquisition of an awareness (which is important because the emancipation of the spectator has been very often posited exclusively in these terms): what this realization actually entails is, first, the axiomatic and dissensual assumption of an equality of intelligences and, then, the verification of that principle in contingent action. In this case we see how Rancière's lesson maintains a certain abstractness precisely because what it describes is meant to be concretely realized always in different forms in different contexts. The theorization of emancipation is thus abstract but not prescriptive, and at the same time not removed from empirical action but rather made available for its appropriation by any subject in any situation whatsoever. 


\section{Indisciplinarity and the aesthetics of knowledge}

Rancière's argument for indisciplinarity proceeds from the conjunction of his axiom of equality and his conception of politics. It brings together a critique of the authoritarian logic that turns knowledge into an instrument for the reproduction of inequality and a critique of the disciplinary logic that uses knowledge as an instrument of classification and control. The discourse of the mandarin, in which an arbitrarily produced condition of intellectual inequality sanctions a certain order of society, and the discourse of the expert in which knowledge is construed as a property and as an element in the distribution of power (as something that gives power differentially, rather than universally and by erasing distinctions) meet in the figure of the pedagogical master and, with a further turn, in that of the philosopher of emancipation.

Rancière's indisciplinarity can thus be discussed as a critical theory of the connection between academic discourse and Foucauldian disciplinary power, and as a verification of the heterogeneity and the whatever singularity of intellectual practice in general. In both cases knowledge is not reduced to a means for, or an expression of, a distribution of roles.

The critique of distinction and distribution presupposes in turn that the idea of community should not be equated with a given order of society, but rather that what is most essential to "community" is found in that order's very inconsistency. A democratic community is a dissensual community: not only a community that is not based on the principle of identitarian belonging and thus accommodates within itself both diversity and conflict, but a community that is constitutionally split by politics that is, by the infinite manifestation of the gap between the existing and the possible.

The opposition between a consensual and a dissensual understanding of community comes out most clearly in Rancière's critique of sociology (which could be said to be the quintessential discipline, much as political philosophy could be the quintessential pedagogy). Sociology is described by Rancière as an instrument of disciplinary regulation, invented as a response to the troubles raised by democratic and aesthetic revolutions (Rancière, "Thinking between Disciplines" 7). The sociological enterprise, Rancière argues, seeks to establish a "rule of correspondence between social condition and the attitudes and judgements of those who belong to it" (Ibid.). "Consequently, and tautologically," comments Pelletier, in the sociological discipline "the fact of being in a certain social location (e.g. being poor) becomes the reason for being in such a location, since people can never do anything else but 'be' an instance of a social location" (Pelletier, "Rancière and the Poetics of the Social Sciences" 272).

This is the key of a further specific kind of disciplinary reductionism that sometimes finds credit in film and media studies: for instance, classifying the average spectatorand the popular film spectator in particular - in terms of its passivity and conformism becomes a way of tautologically affirming the passivity and conformism of specta- 
torship as such, an assumption which is used in turn to justify the classification. In other words, the critique of the spectator's lack of awareness usually depends on sociological assumptions about mass culture and the average spectator that are based in turn on a disciplinary theory of spectatorship. The tautological discourses that result from this consensual articulation are far from being empty or without consequences: they are, on the contrary, bearers of great performative power and have the effect of normalizing judgements - they are what I like to call vérités de La Police (police-truths).

In order to constitute a discipline, both the arbitrariness of the assumptions and norms that inform a given distribution of the sensible and the contingency of the subject's relation to that distribution and those norms are downplayed in favour of a principle of correspondence and determination. This is the model of the consensual logic that ties being and identity, experience and intelligibility, the common and its distribution in such a way that experiences and actions will have perceivable effects in the existing order of discourses and things, as well as a recognisable value in relation to accepted patterns of exchange. This is also the principle that attempts, by regulating the gap between the actual and the possible, to prevent politics (in the Rancièrian sense) from taking place.

Aesthetic experience deregulates this consensual arrangement of the community and manifests itself within and against the order of police. As such, its connection with politics is absolutely primary. Aesthetics, for Rancière, is "much more than a way of appreciation of works of art. It concerns the definition of a logic of experience which neutralizes the circular relationship between knowledge as know-how and knowledge as the distribution of roles. Aesthetic experience eludes the sensible distribution of roles and competences which structure the hierarchical order" (Rancière, "Thinking between Disciplines" 4). The aesthetic regime of the understanding of art is therefore based on an aesthetics of knowledge - that is, on an anarchic sharing of experience and a common practice of critique and research which takes place before and beyond any hierarchy or qualification.

If we disjoin it from the disciplinary aspects usually associated to critique, then, we can see how Rancière's philosophy could be considered in some respects to be a critical theory. In turn, it suggests to reimagine critical theory as the practice of a radical equality and as an indisciplinary extension of the scope of theory itself based on des-identification.

On one hand, indeed, its starting point is always a critical reflection on existing regimes of perception and a problematisation of the principles and coordinates that inform them from the standpoint of equality. "The essence of equality," writes Rancière in On the Shores of Politics, "is not so much to unify as to declassify, to undo the supposed naturalness of orders and replace it with the controversial figures of division" (32-33). The political effect of aesthetic experience lies in the "multiplicity of folds and gaps in the fabric of common experience" (Rancière, "Aesthetic Separation, Aesthetic Community" 11): this effect depends on an original disjunction between 
sense and sense, cause and effect, which, related to the subject, constitutes an act of "des-identification" (Ibid.). The gesture by which a subject emancipates itself from the categories that make its subjectivity intelligible as an identity within the given distribution of the parts of the community corresponds to the gesture by which the free play of aesthetic experience and knowledge can take place.

If critical theory means something in Rancière's universe, and if it can exist at all in this sense, it is the collapse of hierarchies and distinctions in relation to experiences and practices whose scope is that of the common. At the same time, this understanding of critical theory implies its indisciplinary articulation. Rancièrian equality - together with the idea of critique that derives from it - is a dissensual gesture originally devoid of content that has to be constantly re-situated and repeated: it is, to use a concept by Giorgio Agamben, an endless means (Agamben, Means without End x).

On the other hand, then, the gesture that implicates the figure of the theorist and, more generally, disciplinary regimes of understanding in the phenomena they describe goes together with an egalitarian extension of the field of theory as such: academic theory and everyday practices are found on the same plane and their becoming indistinct is taken as the common realisation of emancipation and critique. The idea of the subject that comes out from the declassification of the discourses on subjectivity is that, at once and by the same token, of a critical subject and of a desidentified subject.

In the end, what is distinctively critical in Rancière's writing is that he recognizes as primary and creative, rather than incidental and disruptive, anything that may trouble the coherency of a given regime of perception (including self-perception) and that it then attempts to verify the political potential of these troubles not only as the starting point of its practice but as a common form of the sharing of imagination. In the same way as there is a fundamental correspondence between disciplinary categories and forms of police there is a fundamental link between critique, intellectual equality and political dissensus.

Dissensus is of course to be understood here, in the context of a discussion of academia, as something else than simple debate, the conflict between different discourses or positions, or the mutual relevance of theory and social dissent, but rather as a more fundamental disagreement of sense with sense - a trouble in the supposed identity between sense and sense (see Corcoran in Rancière, Dissensus 2). Disengaged from explication, demystification and the pedagogical regime, film theory and critical theory may thus be reconceived, from a indisciplinary standpoint, as popular practices ("people" names for Rancière the part de sans part) that ceaselessly return to a critique of the given by making their conditions of enunciation hospitable to the emergence of dissensus. 


\section{The scene of dialogue and the sharing of knowledge}

"Verifying equality [...]," argues Pelletier, "involves starting from what is common to both the object and the subject of research" ("Rancière and the Poetics of the Social Sciences" 273). That is, it involves the setting up of a scene of dialogue in which a distribution of roles is not made to count. In the emblematic case of film spectatorship, this scene of dialogue comes to exist when the opposition between the voice and the look is suspended, when the subject of the look and the subject of knowledge are no longer distinguished. The kind of situation or space that is implied in Rancière's understanding of the equality of intelligences is thus a space of aesthetic sharing of experience and of encounters beyond any distinction and distribution of the parts.

In the case of film this space is very clearly the space of spectatorship: an aesthetic understanding of film experience is in fact one that connects without solution of continuity the experience of the film-makers, that of the viewers and that of the theorists and anybody who discusses or writes about film on the basis of the common sharing of film experience. The activity of the critic, for instance, is understood by Rancière not as an explanation but as an extension of film experience and a way to have the text "resonate differently" (Rancière, Baronian and Rosello, "Jacques Rancière and Indisciplinarity" 5): this extension takes place, I would say, in the dimension of spectatorship intended precisely as the common intelligence of film. The logic of cinema - by which "people construct their own poem, their own film, with what is in front of them; and then they prolong it in words" (8) - is, in the end, the logic of film spectatorship and, conversely, the practice of knowledge that corresponds to this logic can only be an indisciplinary practice.

The literature professor, believes Rancière, must "submit the disciplinary to the common in two ways: as a reader that refuses to make literature into his or her own object and as one who travels in all directions that literature traverses" ${ }^{11}$ (Rancière and Davis, "Five Questions for Jacques Rancière" 151). In the same way, the film theorist should give itself, as it were, to the commonality of film experience, refusing to act as a specialist or an expert and thus gaining for herself or himself a greater freedom of practice. The principle of emancipation that establishes aesthetic freedom reflects itself, then, also on academic theory and critical practices that are emancipated through the spectator's emancipation. An indisciplinary practice is the practice of an emancipated theorist and an emancipated theorist in turn is a spectator that pursues its emancipation in any possible directions and situations, including the academic situation.

Incidentally, as Teresa de Lauretis noted, the fortune of film studies was largely made at a moment in which it was not yet structured as an academic discipline and was "not bound by rules of propriety, methodological constraints, disciplinary traditions" so that "routes were unmapped and all sorts of encounters might be made along the way" (de Lauretis, Freud's Drive 16). The theoretical flourishing of the field in the 70s happened not just thanks to a creative and somewhat inevitable 
inter-disciplinarity (17) but, I would add, largely due to the absence of disciplinary authority and institutional guidelines.

The aesthetic regime imagines not only a breaking down of the barriers that separate one art from another, or one discipline from another, but also, more radically, the distinction that separates the intelligence of the artist from that of the subject who contemplates the work, the intelligence of the teacher from that of the student. In the same movement, critique ceases to be the practice that distinguishes between active and passive subjects and opens itself to the more embodied and dissensual dimensions of its own practice. To a free play of aesthetic imagination, which puts on the same plane all subjects and styles of art corresponds a free play of knowledge which deregulates the given connections between kinds of discourses and given positions of enunciation.

By refusing a distribution of roles between critical and non-critical subjects, Rancière's theory of intellectual emancipation is in this sense anticipating the eclipse of film theory and, more generally, of critical theory as academic disciplines. What this eclipse can potentially bring about is a scene where knowledge exists as a common and as well as a form of non-identitarian community where the sharing of knowledge would be more hospitable to the emergence of dissensus.

\section{Academic community}

The indisciplinarity advocated by Rancière requires a redefinition of academic practice as something else than what is practised by academics and of academia as something else than the proper place of experts or intellectuals. The disciplinary gesture, indeed, is already wholly contained in the gesture that evinces and legitimizes the nature of a discourse from the site of its enunciation. Since a declassification of discourses can only take place through a break in the existing distribution of positions, there can strictly speaking be no critical intellectual practice without a constantly renewed dissolution of all forms of authority, exploitation and discipline that condition the sharing of knowledge.

"Academia" first served to name a place (the grove of Akademos, outside the walls of Athens) and academics were those who met in that particular place to engage in a specific kind discourse. The way the term is now used to signify the scientific and intellectual society as a whole retains a trace of this initial communitarian logic: academic practice is qualified through a system of sanctions that emanates from sanctioned individuals and "proper" places. One cannot consider oneself an academic, and surely cannot exercise an academic profession, unless one attends the grounds of Academia, so to speak, and receives approval and authorisation not just from his or her peers, but from academic institutions as such. These institutions, moreover, are increasingly defined and constrained by administrative requirements and socioeconomic planning which are further estranged from the commonality of critique and the conditions for a free sharing of knowledge. So that the academic community finds itself doubly subordinated: to the powers and practices that sanction academics as a 
special part of society and to the requirements and binds that their role in the existing society impose on their practice.

The disciplinary system, upon which the present corporate organisation of universities significantly depends, does not so much enable - as it is sometimes claimed - than merely regulate and discipline the universality of academic practice. This universality should in fact be regarded as primary and prior to any institutional formation, for it corresponds to the academia as an ideal space, to a scene of critical reflection that has no proper place and that anybody can occupy at any time without qualification. More concretely, "academic" would be any instance of dialogue which begins from the possibility of a critical declassification of discourses and proceeds to realise the general equality of intelligences within the existing forms of the distribution of knowledge. Academia in this sense is neither a discourse nor a place, but rather a scene that troubles the disciplinary regime of understanding of knowledge.

Imagined in this way, the academia would also be the expression of a nonidentitarian community, where theoretical practice remains open to the possibility of bringing into existence something unforeseeable in the given distribution of the sensible. The community of scholars described by Paul Goodman, which names in his work the educational dimension of the university against its institutional administration, may thus be taken as the scene of a dissensual community both in the sense that it would be a community within society but other to it (a heterotopia) (see Goodman 1964, 170) and in the sense that it would be a community more hospitable to the emergence of dissensus.

Among other occasions, Rancière has discussed the idea of a dissensual community based on the equality of intelligences in his dialogue with the Swiss artist Thomas Hirschhorn, whose performances, precisely, mean to sustain spaces for unprogrammed personal and intellectual encounters. "The general phenomenon revealed by this kind of experiences," writes Rancière, "is the presence of powerful investments for knowledge, thought, art, and any experience of this type in places where they aren't expected, among individual whose business they aren't supposed to be" (Rancière and Hirschhorn, "An Electronic Conversation" 105). "The political power of art," he continues, "is in its ability to create public spaces" conceived as spaces that affirm anybody's ability to see, produce and think (106).

The academia should be in this sense a space where the freedom of a dissensual community can be experienced, and where one could experiment with the possibilities of maintaining these spaces of play constantly available and open to anybody whatsoever (see Rancière, Carnevale and Kelsey, "Art of the Possible" 259). Like in the case of art practice, indeed, academic indisciplinarity "supposes the creation of a space without boundaries which is also a space of equality" as well as "forms of creativity manifested in objects and behaviours that testify to everyone's capacities and to our inherent power of resistance" (Ibid.). In this direction, it becomes possible to imagine new modes of academic practice, as well as more emancipated forms of 
the relation of academics and non-academics toward critical thought, on one hand, and, on the other, toward existing cultural and political institutions.

In some respects and within certain limits, this conception of academic practice as a space for dissensual reflection is still accepted in the university: "even though academic reaction has been in decline since the 1980s and the analytical empire pursues like everywhere else its colonising enterprise," Rancière conceded, "philosophy still remains [in France] a place where an indisciplinary thought can be practised [...]" (Rancière and Davis, "Five Questions for Jacques Rancière" 152). Philosophy is thus proposed by Rancière as the model of a thought and of a practice that strive to remain hospitable to the emergence of dissensus and as a regime of understanding in which discourses and styles from different thoughts can be articulated together as the thought of all (152-153). This understanding of philosophy, however, does not survive easily and, sometimes, only survives in the form of a privilege.

Ideas of secession and independence from corporate academic institutions, or at least of the decentralisation of academic practice (Schecter, Critical Theory in the Twenty-First Century 15), seem then to reaffirm themselves as viable, if not necessary, solutions to the gradual erosion of academic freedom in the context of the intensified neoliberal governance of universities and the rising casualisation of intellectual work in general. These alternative forms of the organisation of academic practice may then potentially encounter those forms of aesthetic and political practice that, like Hirschhorn's, concern themselves with the imagination of dissensual communities.

The declassification of discourses which is at the core of a critical understanding of the world must in this sense proceed together with a des-identification of subjects and with ways of conceiving and organising the common that are alternative to the logic of identity, both in the form of belonging and in that of representation. As we have argued, the logic of identity is both the logic that distributes positions according to essential qualities and the logic that binds forms of subjectivation to their intelligibility and regulation. So, if being is not the process of becoming, and constantly adhere to, what one can be said to be, then emancipation must be something radically incompatible with the politics of representation - all while not negating individual responsibility, a discourse of emancipation should search for political agency in a dimension of practices that remain distinct from their traces, of encounters beyond recognition, of forms of action other than activity and of subjects before qualifications. In the end, the indisciplinary space of the academia can be imagined as the space of a community based on something else than identity and consensus and constantly working toward different ways of practising knowledge in everyday life as an encounter - vers des nouveaux arts de faire la connaissance.

\section{Notes}

1 "Il doit en somme soumettre de deux façons le disciplinaire au commun : comme lecteur qui refuse de faire de la littérature son objet et comme voyageur dans toutes les directions qui traverse la littérature." Translation mine. 


\section{Works Cited}

Agamben, Giorgio. Means without End: Notes on Politics. University of Minnesota Press, 2000. Baumbach, Nico. "Jacques Rancière and the Fictional Capacity of Documentary." New Review of Film and Television Studies 8, vol. 1, 2010, pp. 57-72.

Bowman, Paul (ed.). Rancière and Film. Edinburgh University Press, 2013.

Foucault, Michel. The History of Sexuality: Volume 1, An Introduction. Pantheon, 1978.

Goodman, Paul. Compulsory Mis-education and The Community of Scholars. Vintage, 1964.

de Lauretis, Teresa. Freud's Drive: Psychoanalysis, Literature and Film. Macmillan, 2008.

Rancière, Jacques. On the Shores of Politics. Verso, 1995.

- - . "Thinking between Disciplines: An Aesthetics of Knowledge." Parrhesia 1, 2006, pp. $1-12$.

- -. “The Emancipated Spectator." Artforum 45, vol. 7, 2007, pp. 271-280.

- --. The Emancipated Spectator. Verso, 2009.

- - - Dissensus: On Politics and Aesthetics. Edited and Translated by Steven Corcoran. Continuum, 2010.

- - -. "Aesthetic Separation, Aesthetic Community: Scenes from the Aesthetic Regime of Art." Art and Research 2, vol. 1, 2008, pp. 1-15.

Rancière, Jacques, Fulvia Carnevale and John Kelsey. "Art of the Possible." Artforum 7, vol. 45, 2007, pp. 256-269.

Rancière, Jacques, Marie-Aude Baronian and Mireille Rosello. "Jacques Rancière and Indisciplinarity." Art \& Research 2, vol. 1, 2008, pp. 1-10.

Rancière, Jacques and Oliver Davis. "Five Questions for Jacques Rancière / Cinq Questions à Jacques Rancière: An interview with Oliver Davis," Contemporary French and Francophone Studies 16, vol. 2, 2012, pp. 151-156.

Rancière, Jacques and Thomas Hirschhorn. "An Electronic Conversation between Thomas Hirschhorn and Jacques Rancière: Presupposition of the Equality of Intelligences and Love of the Infinitude of Thought." Theory, Culture \& Society 7/8, vol. 31, 2014, pp. 101-110.

Pelletier, Caroline. "Rancière and the Poetics of the Social Sciences." International Journal of Research \& Method in Education 32, vol. 3, 2009, pp. 267-284.

Schecter, Darrow. Critical Theory in the Twenty-First Century. Bloomsbury, 2013. 